Research Paper

\title{
Idelalisib and bendamustine combination is synergistic and increases DNA damage response in chronic lymphocytic leukemia cells
}

\author{
Prexy Modi ${ }^{1}$, Kumudha Balakrishnan ${ }^{1}$, Qingshan Yang $^{1}$, William G. Wierda ${ }^{2}$, \\ Michael J. Keating ${ }^{2}$ and Varsha Gandhi ${ }^{1,2}$ \\ ${ }^{1}$ Department of Experimental Therapeutics, The University of Texas MD Anderson Cancer Center, Houston, TX, USA \\ 2 Department of Leukemia, The University of Texas MD Anderson Cancer Center, Houston, TX, USA \\ Correspondence to: Varsha Gandhi, email: vgandhi@mdanderson.org \\ Keywords: CLL, bendamustine, idelalisib, DNA damage, B cell receptor \\ Received: January 16, $2017 \quad$ Accepted: January 25, $2017 \quad$ Published: February 07, 2017
}

\section{ABSTRACT}

Idelalisib is a targeted agent that potently inhibits PI3Kס which is exclusively expressed in hematological cells. Bendamustine is a well-tolerated cytotoxic alkylating agent which has been extensively used for treatment of chronic lymphocytic leukemia (CLL). Both these agents are FDA-approved for CLL. To increase the potency of idelalisib and bendamustine, we tested their combination in primary CLL lymphocytes. While each compound alone produced a moderate response, combination at several concentrations resulted in synergistic cytotoxicity. Idelalisib enhanced the bendamustine-mediated DNA damage/repair response, indicated by the phosphorylation of ATM, Chk2, and p53. Each drug alone activated yH2AX but combination treatment further increased the expression of this DNA damage marker. Compared with the control, idelalisib treatment decreased global RNA synthesis, resulting in a decline of early-response and short-lived MCL1 transcripts. In concert, there was a decline in total Mcl-1 protein in CLL lymphocytes. Isogenic mouse embryonic fibroblasts lacking MCL1 had higher sensitivity to bendamustine alone or in combination compared to MCL1 proficient cells. Collectively, these data indicate that bendamustine and idelalisib combination therapy should be investigated for treating patients with CLL.

\section{INTRODUCTION}

Chronic lymphocytic leukemia (CLL) is a malignancy that is driven by active B-cell receptor (BCR) pathway. The primary BCR down-stream network includes two pivotal enzymes, Bruton's tyrosine kinase and phosphatidyl inositol three kinase (PI3K). Both BTK and PI3K isoform delta are selectively expressed in hematopoietic cells specifically normal and malignant B-cells such as CLL lymphocytes. This exclusive expression provided an impetus to design potent and selective inhibitors of these two proteins. Ibrutinib, a BTK poison and idelalisib a PI3K delta antagonist were tested in CLL and demonstrated on-target effect during preclinical experimentations and efficacy during clinical trials. Both drugs were FDA approved for patients with CLL.
As described above, PI3K delta isoform is pivotal in the BCR axis [1] and is selectively blocked by idelalisib [2]. Idelalisib promotes apoptosis in CLL by disrupting molecular pathways related to BCR signaling. Furthermore, idelalisib blocks signals from the microenvironment, tumor cell and microenvironment interactions, and mitigates pseudo-emperipolesis [3-6]. Clinically, as a single agent during phase I investigations, the drug has been well-tolerated and has prolonged survival of patients with CLL [2]. In combination with rituximab, during phase II clinical trial, the efficacy trend was maintained and this resulted in approval of the drug for relapsed/refractory CLL disease $[1,2,7,8]$.

In the front-line setting, the idelalisib and rituximab combination was tested for older patients with CLL [9]. Similarly for another study, treatment-naïve CLL patients were treated with idelalisib for two months as monotherapy followed by combination with ofatumumab 
[10]. In both these studies, responses were observed however with a toxicity profile which was much worse than what was observed in the relapsed/refractory disease. The toxicity was identified as immune-mediated and hence was more pronounced in front-line treatment $[10,11]$.

From phase I, phase II in previously treated CLL, and phase II in newly-diagnosed CLL, a few points emerged. First, while the drug was well-tolerated during earlier studies, in treatment naïve patients, there was unacceptable toxicity profile. Second, responses were mostly partial and complete remissions were limited. Third, in both cohort of patients (previously untreated or treated), similar to other BCR pathway antagonists, there was egression of CLL cells from lymph node which remained in peripheral blood. Finally, there is a need to combine idelalisib with CLL-specific agents that may result in deeper responses without much untoward toxicity.

Chlorambucil, cyclophosphamide, and bendamustine are three alkylating agents that have been used for decades for treatment of CLL. Of these three, regarding potency in the clinic, the cyclophosphamide is the strongest, followed by bendamustine, and chlorambucil. However, cyclophosphamide results in high untoward toxicity, a feature not favorable to combine with idelalisib. Bendamustine not only possesses alkylating agent properties but is also well-tolerated and FDA approved for patients with CLL along with established treatment recommendations. $[12,13]$.

Previously, we have demonstrated utility of bendamustine in preclinical setting for primary CLL cells and shown synergistic or additive interactions with fludarabine [14]. Importantly, both p53 positive and p53 mutated CLL responded similarly to bendamustine $[15,16]$. The mechanism of CLL lymphocyte death elicited by bendamustine was due to DNA damage and repair response. Because PI3K inhibitors, including idelalisib also result in DNA damage, we postulated that combination of idelalisib to bendamustine may result in additive or synergistic cytotoxicity due to enhanced DNA damage. When used alone, bendamustine was more active in suspension cultures of CLL but stromal microenvironment protected CLL cells from bendamustine-mediated cytotoxicity [14]. One of the primary pathways of microenvironment-induced CLL cell survival is BCR axis that includes the PI3K/Akt cassette. Because idelalisib mitigates the BCR nexus, we hypothesized that microenvironment-induced resistance to bendamustine cell death of CLL lymphocyte may be abrogated with idelalisib addition.

In the current project, we tested that idelalisibmediated suppression of BCR signaling would sensitize CLL cells to bendamustine, and this mechanism-based combination may lead to a synergistic interaction. We evaluated the cytotoxicity induced by idelalisib or bendamustine alone or in combination in primary CLL cells and the impact of this combination on DNA damage response and $\mathrm{Bcl}-2$ family survival protein levels which are regulated by PI3K/Akt pathway. Our data demonstrate that this combination is synergistic, and we suggest a mechanism by which idelalisib increased the cytotoxicity of bendamustine.

\section{RESULTS}

\section{Idelalisib and bendamustine combination is synergistic}

Treatment of primary CLL cells with idelalisib alone (Figure 1A), bendamustine alone (Figure 1B), or the combination for 24 hours (Figure 1C;n=9) revealed that single agent idelalisib induced moderate but statistically significant cytotoxicity (i.e., apoptosis) in a dose-dependent manner, ranging from $4 \%$ to $16 \%$ ( $p=0.002$ to $<0.0001$ for each concentration). Whereas single agent bendamustine resulted in 6\%-33\% $(p=$ 0.002 to $<0.0001$ for each concentration) cell death. Combination of idelalisib and bendamustine at clinically relevant concentrations resulted in $13 \%$ to $49 \%$ of apoptosis ( $p=<0.0001$ for each concentration). At each drug concentration, compared to single agent apoptotic response, there was an increase in the level of cell death when both drugs were combined together.

This dose-response profile led us to investigate whether idelalisib and bendamustine combination could be synergistic combination. To test this, we plotted the apoptotic values obtained from Figure 1C and analyzed by the median-effect method using CalcuSyn software. The calculated combination index $(\mathrm{CI})$ was $<0.8$ for all the samples (except for 1 sample treated with low concentrations of both drugs) indicating synergy (Figure 1D).

\section{DNA damage response was enhanced with combination of idelalisib and bendamustine}

Bendamustine is an alkylating agent known to induce DNA damage response. $\gamma \mathrm{H} 2 \mathrm{AX}$ is a prominent marker of DNA damage response [17] and could be measured using flow-cytometry assay as shown in the plots (Figure 2A). CLL primary cells were either untreated or treated with idelalisib alone, bendamustine alone or combination. Control i.e. DMSO only treated CLL lymphocytes showed a minimal positivity for $\gamma \mathrm{H} 2 \mathrm{AX}$. Compared to the control, single agent idelalisib and single agent bendamustine demonstrated increased $\gamma \mathrm{H} 2 \mathrm{AX}$. Furthermore, when both drugs were incubated simultaneously, the combination treatment significantly enhanced DNA damage response, according to both flow cytometry (Figure 2B) and immunoblot analysis (Figure $2 \mathrm{C})$. When CLL primary cells were stimulated with $\alpha \operatorname{IgM}$, 


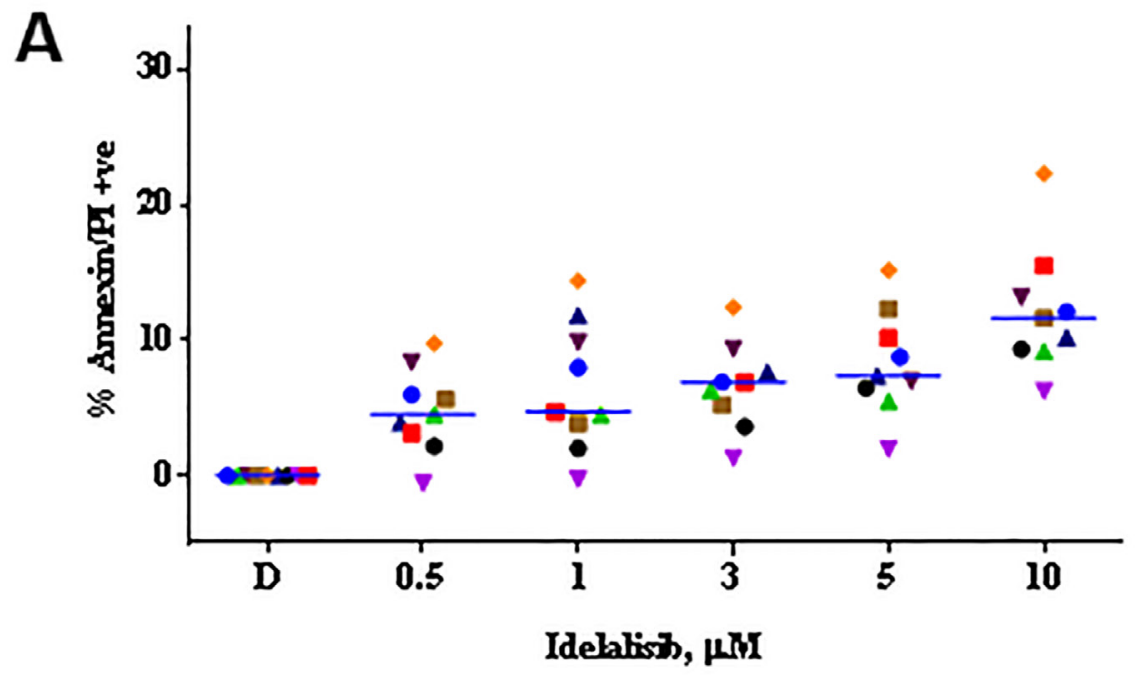

B

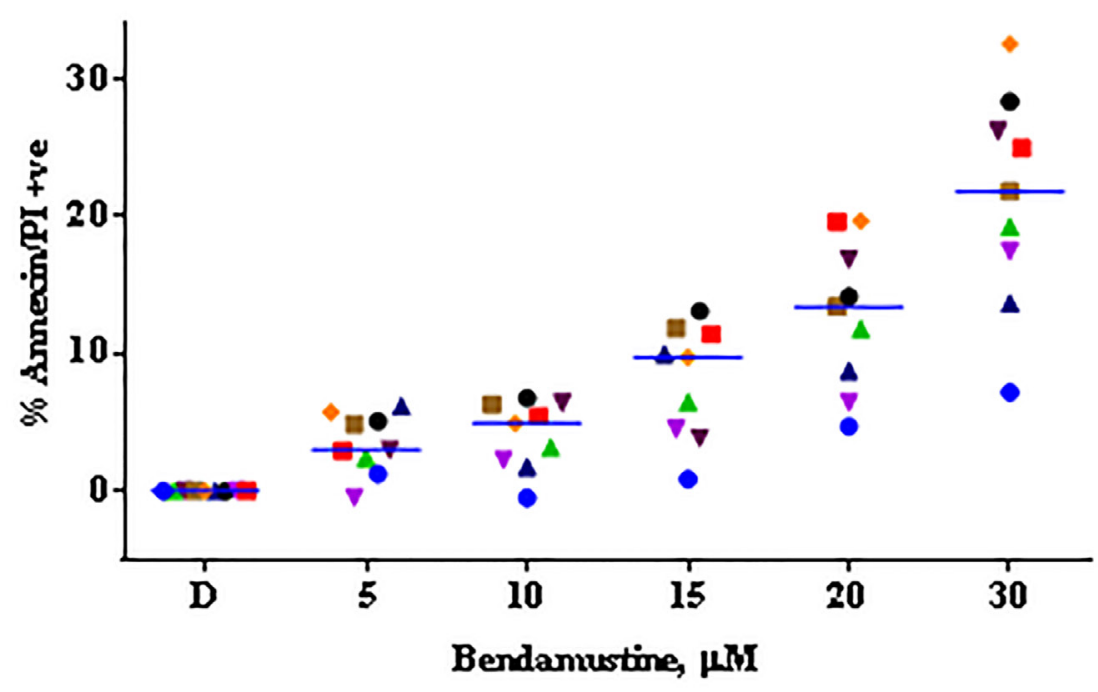

C

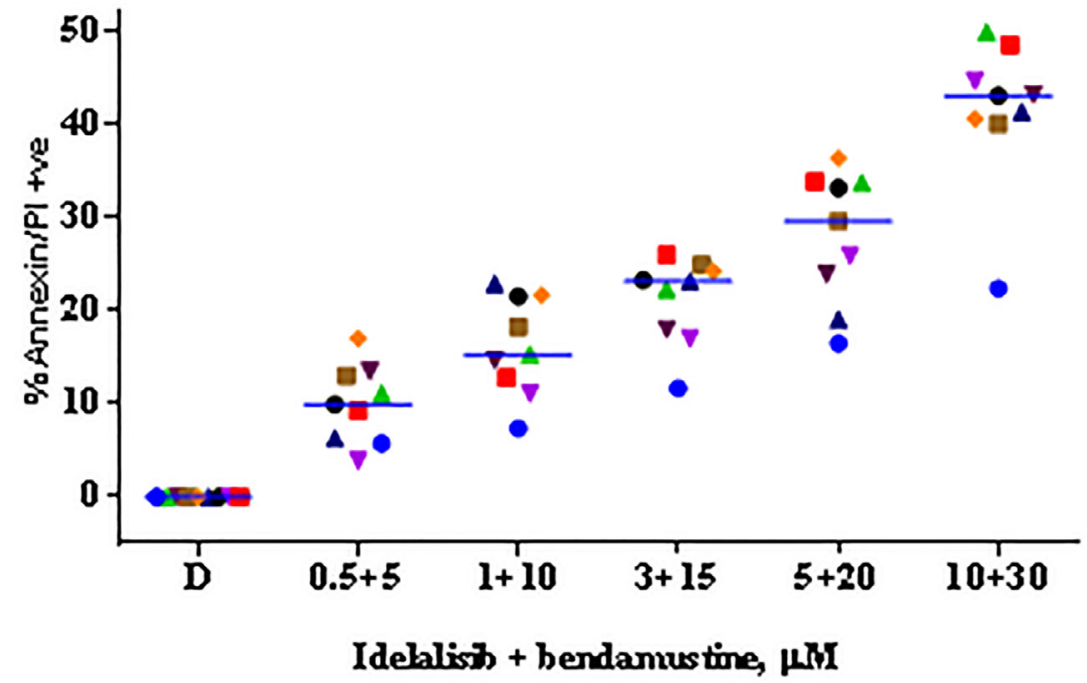




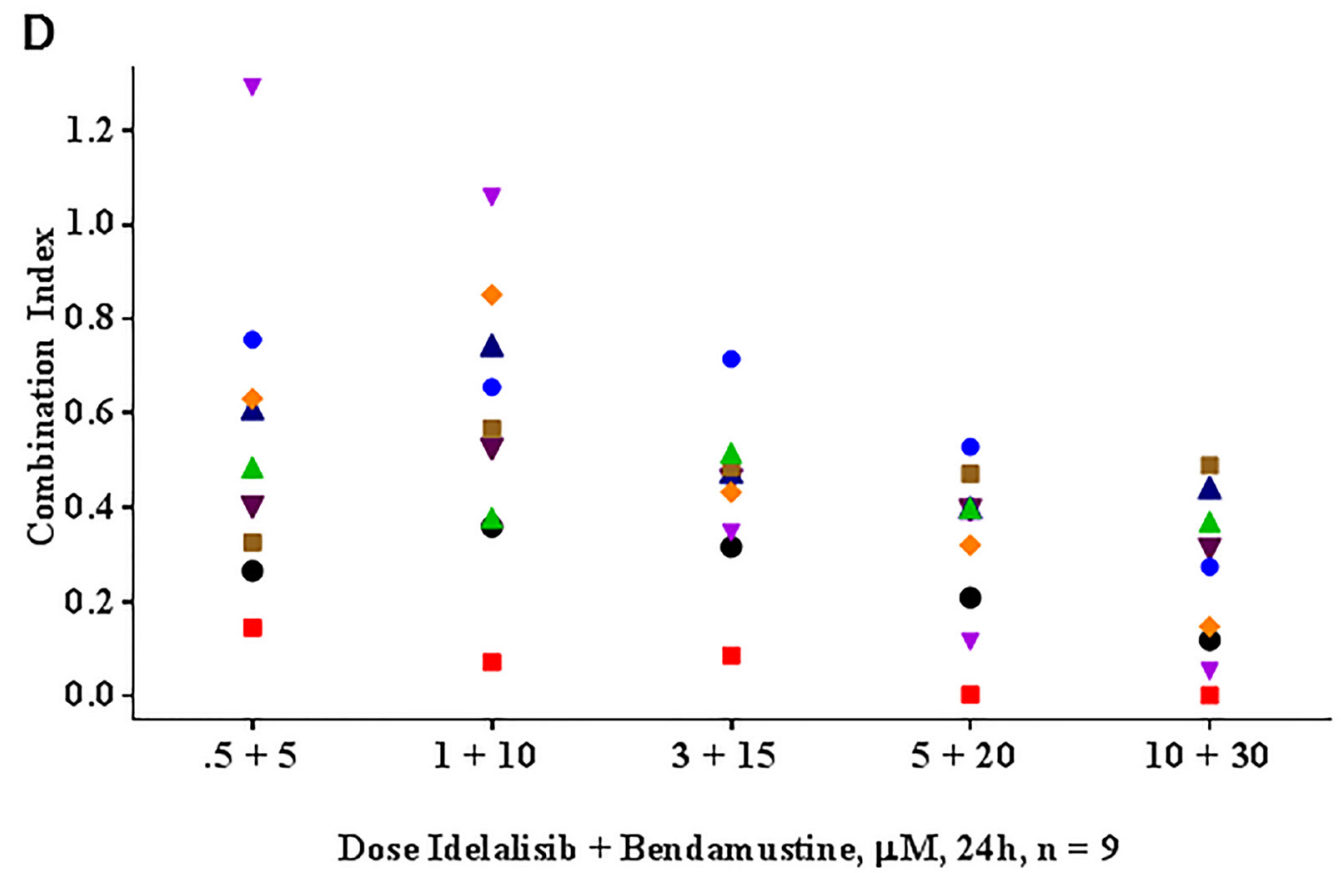

Figure 1: Idelalisib and bendamustine combination results in synergistic cytotoxicity. A. Dose-dependent cytotoxicity of idelalisib alone or B. bendamustine alone or C. both in combination. Freshly isolated chronic lymphocytic leukemia (CLL) cells from 9 patients were incubated with the indicated concentrations of single agent idelalisib A., single agent bendamustine B., or both agents $\mathbf{C}$. simultaneously for 24 hours. Cells were harvested and then stained with Annexin V/PI. The level of apoptosis for each treated sample was detected using flow cytometry, and the apoptotic cells were indicated by the cell population in the lower right, upper right, and upper left quadrants. The values were represented as percent control to untreated time matched control (DMSO; D) samples. Each colored symbol represents a CLL patient sample (CLL516, CLL944, CLL267, CLL109, CLL973, CLL781, CLL247, CLL661, and CLL112). Horizontal bar for each concentration represents median value. D. Evaluation of the combination index (CI) for the idelalisib and bendamustine combination. The apoptotic population from the combination treatment $\mathbf{C}$. was used for fractional analysis. Calcusyn software was used for an output of the CI calculated by the fraction affected and the non-constant ratios of the drugs. The calculated combination index $(\mathrm{CI})<1$, $=1$, and $>1$ indicate synergistic, additive, and antagonistic interactions, respectively. Abbreviation: $\mathrm{h}$, hours.

there was a slight decrease in DNA damage response (Figure 2C).

We further evaluated the effects of these agents on other proteins involved in DNA damage/repair signaling pathways. Compared to the control, bendamustine alone increased phosphorylation of ATM(Ser1981) and Chk2(Thr68), an effect that was further enhanced by combination treatment. Additionally, bendamustine alone and in combination with idelalisib resulted in stabilization of p53 protein, marked by phosphorylation of p53(Ser15). Overall, these observations indicate that idelalisib enhanced the DNA-damage response elicited by bendamustine.

\section{Idelalisib treatment decreases global RNA synthesis and impacts short-lived mRNAs}

Consistent with previous studies of PI3K $\alpha$ and $\beta$ isoforms, [18] we found that idelalisib-treated cells had significantly less global RNA synthetic capacity than control cells (47\%-71\% decrease; $n=4$; Figure 3A). We next examined which particular mRNA transcripts are being depleted with idelalisib treatment. In CLL, MCL1 and BCL2 are the members of the BCL2 family antiapoptotic proteins, [19]. Our results showed that, in unstimulated cells, idelalisib treatment significantly decreased MCL1 mRNA expression (by 30\%); Of note, MCL1 mRNA expression was increased by IgM stimulation, but decreased again with idelalisib treatment (Figure 3B; upper panel). In contrast, BCL2 mRNA expression did not change significantly (Figure 3B; lower panel).

\section{Idelalisib treatment decreases Mcl-1 but not Bcl-2 protein levels in CLL cells}

In order to examine if the transcription results obtained above are in conjunction with translation, we evaluated the protein levels of Mcl-1 and Bcl-2. CLL primary cells from one patient sample (CLL599) was either unstimulated or stimulated with $\alpha \operatorname{IgM}$ and treated with $5 \mu \mathrm{M}$ of idelalisib for increasing time points (30 min, $2 \mathrm{~h}$ and $24 \mathrm{~h}$ ) and the immunoblot technique was carried out to evaluate $\mathrm{Mcl}-1$ and $\mathrm{Bcl}-2$ proteins. Additional 

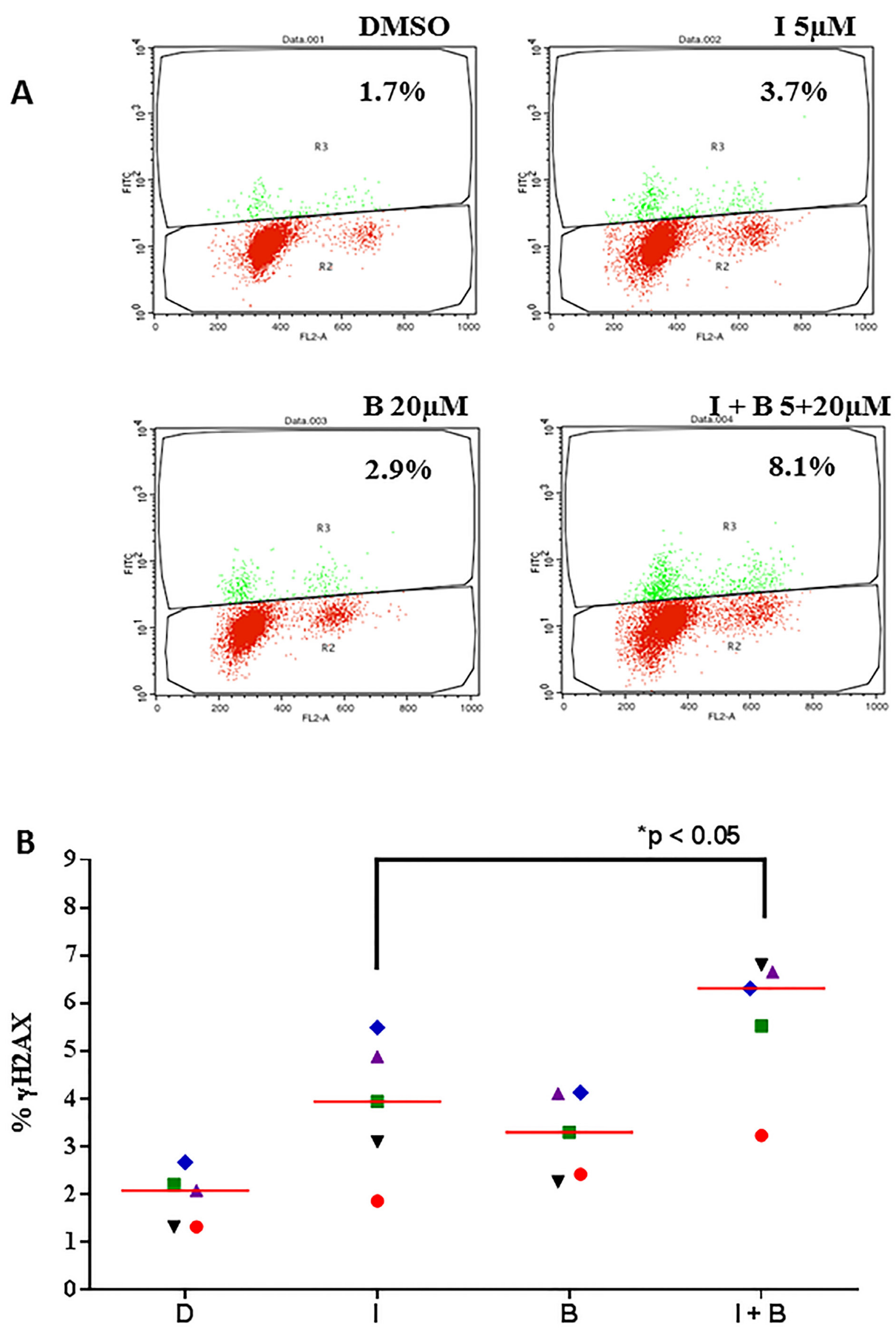


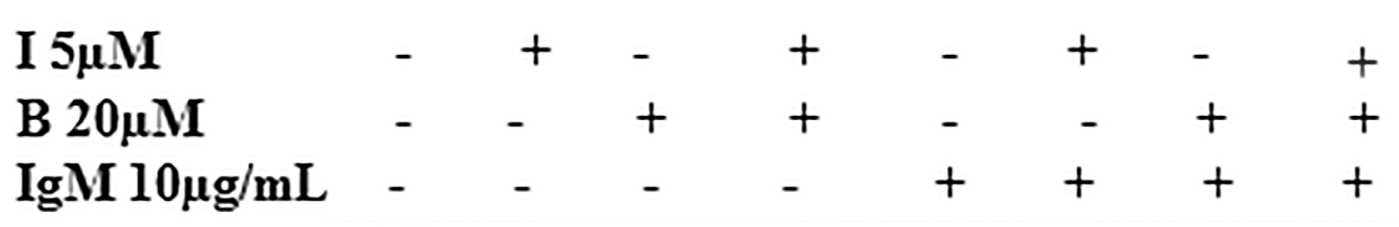

pP53

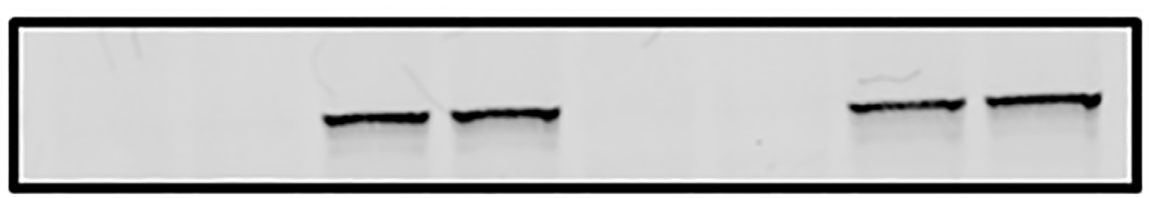

P53
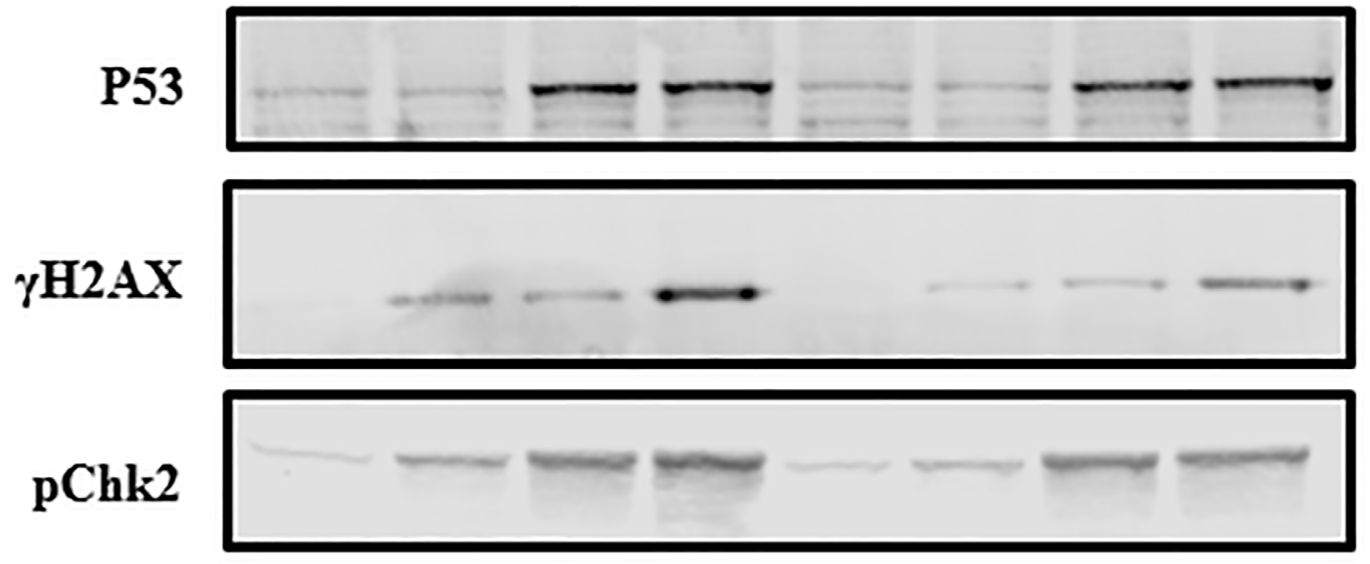

Chk2

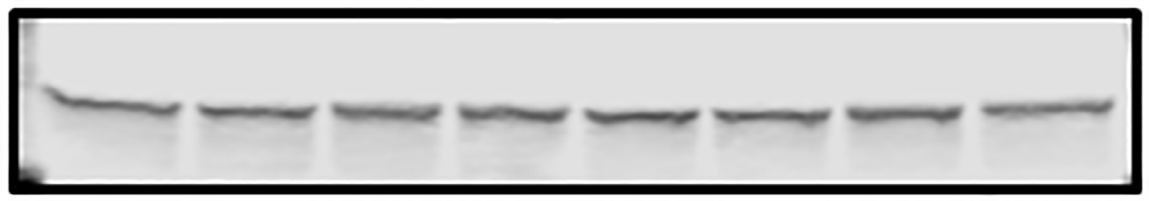

pATM
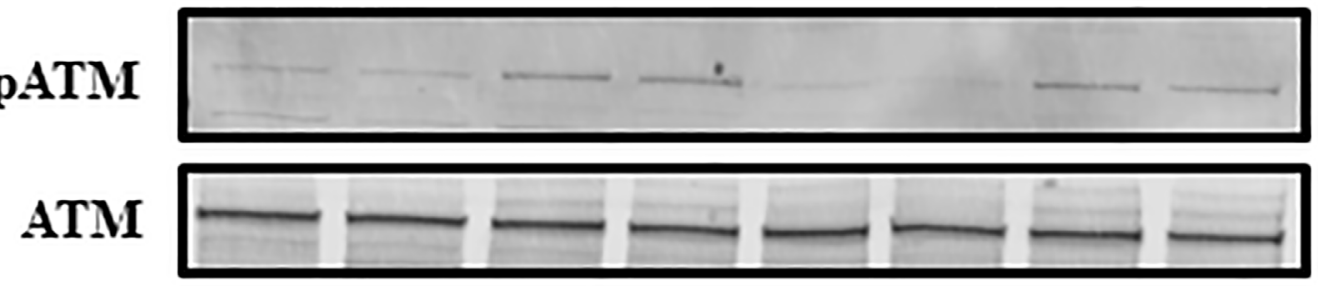

GAPDH Also in 5B

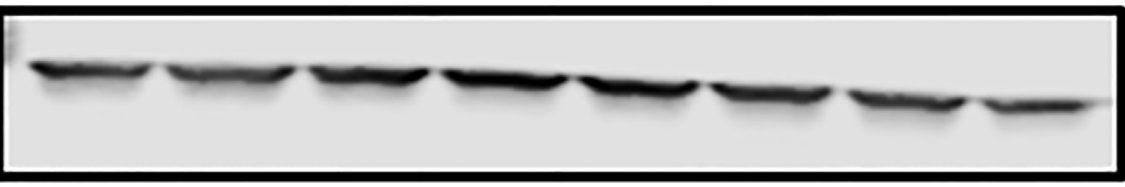

Figure 2: Idelalisib and bendamustine combination results in enhanced DNA damage response. A.. Induction of $\gamma \mathrm{H} 2 \mathrm{AX}$ (measure of DNA damage response) after treatment with idelalisib, bendamustine, or the combination. Primary cells were treated with DMSO (D), idelalisib (I, $5 \mu \mathrm{M})$ alone, bendamustine (B, $20 \mu \mathrm{M})$ alone, or both idelalisib and bendamustine $(5 \mu \mathrm{M}+20 \mu \mathrm{M}$, respectively) for 24 hours. The cells were then harvested, fixed with ethanol, incubated with goat serum for 1 hour, and probed with the primary antibody $\gamma \mathrm{H} 2 \mathrm{AX}$. Cells were washed and then co-incubated with PI and DNase-free RNase and analyzed for fluorescence signal on flow cytometry for DNA damage response. Fluorescent cells, with an upward shift were marked as $\gamma \mathrm{H} 2 \mathrm{AX}$-positive cells. B.. Data similar to that in Figure 2A were collected from 5 patients with CLL (CLL514, CLL455, CLL327, CLL137, and CLL103). Horizontal bar represents median value. The significance of the differences between treatment groups was determined by a paired 2-tailed Student $t$-test. C.. Effect of idelalisib, bendamustine, and combination treatment on DNA damage proteins in CLL cells. Primary cells were either unstimulated or stimulated with $\alpha \operatorname{IgM}(10 \mu \mathrm{g} / \mathrm{mL})$ for 30 minutes. The cells were then treated with DMSO, idelalisib alone $(5 \mu \mathrm{M})$, bendamustine $(20 \mu \mathrm{M})$ alone, or both idelalisib and bendamustine $(5 \mu \mathrm{M}+20 \mu \mathrm{M}$, respectively) for 24 hours. Cells were harvested, lysed and analyzed using immunoblot technique to detect the protein levels of phospho- and total-p53, $\gamma \mathrm{H} 2 \mathrm{AX}$, phospho- and total-Chk2, and phospho- and totalATM. Glyceraldehyde 3-phosphate dehydrogenase (GAPDH) was used as a control for equal protein loading. 
A

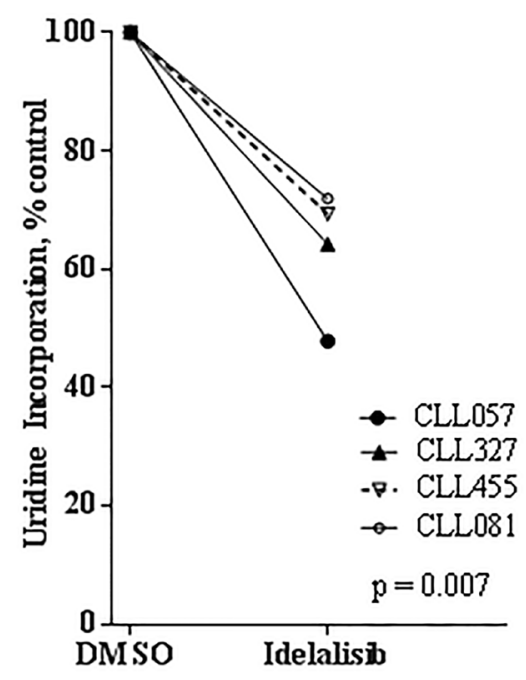

B
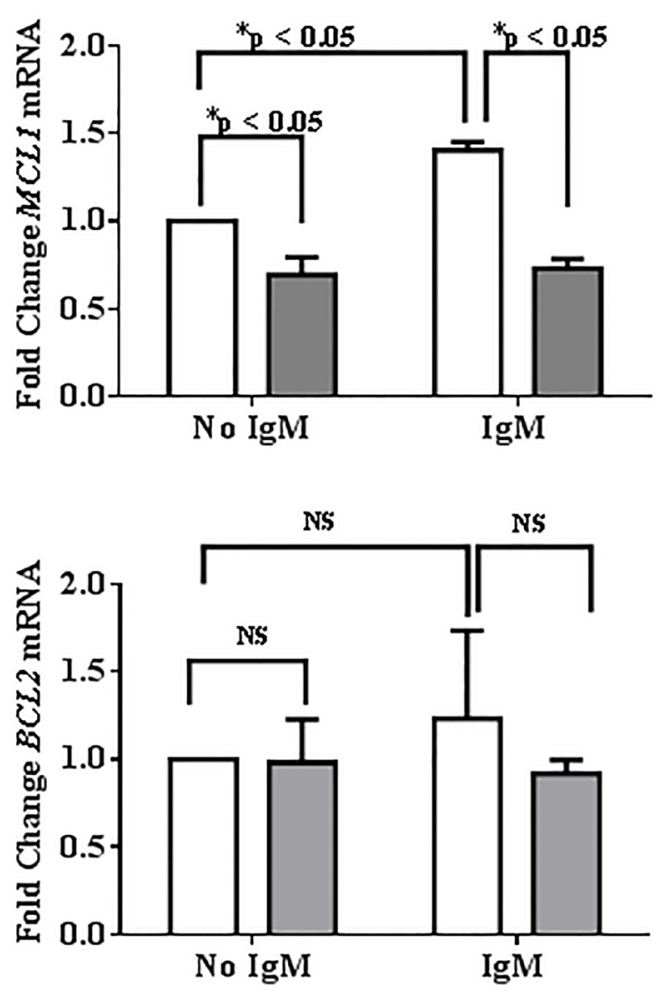

Figure 3: Effect of idelalisib on global RNA synthesis and MCL1 transcript levels. A. Inhibition of global RNA synthesis by idelalisib in primary CLL cells. CLL peripheral blood mononuclear cells isolated from patient samples were treated with dimethyl sulfoxide (DMSO) or with idelalisib $(5 \mu \mathrm{M})$ for 24 hours. The cells were co-incubated with $\left[5,6-{ }^{3} \mathrm{H}\right]$-uridine for 30 minutes before harvesting, and the amount of radioactivity incorporated into the cells was measured using a scintillation counter. Radioactivity was calculated and normalized to the DMSO control. Experiments using 4 patient samples (CLL057, CLL327, CLL455, and CLL081) were performed in triplicate. The significance of the differences between treatment groups was determined by a paired 2-tailed Student $t$-test. B. Decreased MCL1 mRNA expression, with no change in $B C L 2 \mathrm{mRNA}$ expression, in idelalisib-treated CLL cells. Primary cells were either unstimulated or stimulated with $\alpha \operatorname{IgM}(10 \mu \mathrm{g} / \mathrm{mL})$ for 30 minutes. Cells then were treated with DMSO or idelalisib $(5 \mu \mathrm{M})$ for 24 hours and total RNA was extracted and quantified. Isolated RNA was analyzed by real-time RT-PCR with primers and probes for MCL1 and BCL2 mRNA transcripts. MCL1 and $B C L 2$ gene expression levels were measured and normalized to the $18 S$ ribosomal RNA as an endogenous control, and each experiment was normalized to the DMSO control. The results are shown for 8 patient samples (CLL075, CLL483, CLL454, CLL293, CLL068, CLL354, CLL653, and CLL516). Each bar represents mean +/- SEM for the 8 patient samples. The $\mathrm{p}$ values were calculated using paired $t$-test. Abbreviations: NS, not significant. 
samples (CLL525 (24 h), CLL103 (24 h) and CLL103 $(48 \mathrm{~h}))$ were evaluated for the same proteins. Consistent with our mRNA data, idelalisib treatment decreased Mcl-1 protein but not $\mathrm{Bcl}-2$ protein levels (Figure 4A).

\section{Effect of single agent bendamustine and in combination with idelalisib on Mcl-1 expression}

Single agent bendamustine also depleted MCL1 mRNA levels in primary CLL cells $(n=8)$ however not to the extent of idelalisib induced depletion tested in the same samples (Figure 5A). When the protein levels were evaluated with bendamustine and bendamustine and idelalisib combination, in both unstimulated and $\alpha \operatorname{IgM}$ stimulated cells ( $24 \mathrm{~h}$ and $48 \mathrm{~h}$ ) there was no marked changes in Mcl-1 protein levels (Figure 5B). On same note, there were no significant changes in BCL2 mRNA (Supplemental Figure 1) or protein levels (Figure 5B). Quantitation of immunoblots for Mcl-1 protein revealed that although single agent bendamustine does not alter the Mcl-1 protein levels, this agent in combination with idelalisib does significantly enhance the depletion of this short-lived protein (Figure 5C).

\section{Impact of Mcl-1 loss on bendamustine and combination-induced cytotoxicity in MEFs}

Mcl-1, an anti-apoptotic protein of Bcl-2 family is considered important for CLL cell survival. In addition, BCR activation enhances Mcl-1 protein levels and inhibition of BCR signaling with kinase inhibitors deplete Mcl-1. Consistently, our current results demonstrate that idelalisib inhibits Mcl-1 transcript and protein levels, with no differential effect with bendamustine. To directly assess the role of Mcl-1 in bendamustine-induced cytotoxicity, we tested the apoptotic response of isogenic MEFs (Supplemental Figures 2 and 3) treated with idelalisib, bendamustine, or combination. Bendamustine- $(p=0.021)$ or combination-treated ( $p=0.017)$ MEFs lacking MCL1 had significantly higher apoptotic cells compared to wildtype MEFs (Figure 6); indicating that the combination regimen potently downregulates Mcl-1 and thus enhance the apoptosis in CLL cells. This differential effect was not observed with idelalisib $(p=0.478)$.

\section{DISCUSSION}

Bendamustine alone showed a dose- and timedependent cytotoxicity of quiescent CLL lymphocytes (Figure 1B). The primary mechanism of cell death is damage of DNA, genotoxic stress, and apoptosis [14, 20]. While idelalisib-induced apoptosis was minor (Figure 1A), the couplet of bendamustine and idelalisib resulted in synergistic combination at many different concentrations (Figure 1D). This is in concert with a prior report where combination of idelalisib at $0.5 \mu \mathrm{M}$ resulted in sensitization of CLL cells to bendamustine $(25 \mu \mathrm{M})$ induced cell death [15]. Mechanistically, we provide two actions of idelalisib to enhance bendamustine's cytotoxic effect in CLL lymphocytes; first is an impact on DNA damage and repair response and second is a depletion of Mcl-1 protein. Down-regulation of CD69, a biomarker in CLL, by idelalisib has been previously shown to be responsible for sensitization of CLL cells to bendamustine [15].

Bendamustine is an established alkylating agent resulting in double strand breaks. It is $4-\{5-$ [bis(2chloroethyl)amino]-1-methyl-2-bezimidazolyl $\}$ butyric acid hydrochloride. The nitrogen mustard group of bendamustine is similar to that in chlorambucil $[12,21]$. However, randomized study comparing chlorambucil to bendamustine suggested increased overall response rate with bendamustine [22]. Nitrogen mustard induced damage results in monoadducts, biadducts, and intra- and interstrand cross-links in DNA. As a consequence of this damage response, as expected, bendamustine resulted in induction of gammaH2AX (Figure 2A) along with other hallmark features such as Chk2 phosphorylation (Figure 2B). Paradoxically, and not expected, treatment of CLL cells to idelalisib alone also resulted in initiation of DNA damage response (Figure 2A and 2B and unpublished data). Additionally, in combination with bendamustine, idelalisib resulted in stabilization of $\mathrm{p} 53$ protein, marked by phosphorylation of $\mathrm{p} 53$ (Ser15), Chk2 phosphorylation, and induction of gammaH2AX; all markers of DNA damage. Phosphorylation of $\mathrm{p} 53, \mathrm{Chk} 2$, and $\mathrm{H} 2 \mathrm{AX}$ are mediated through active ATM. [14, 23, 24] It is worthy to mention that none of the patient samples studied had 11q or $17 \mathrm{p}$ deletion, the sites for ATM and $\mathrm{p} 53$, respectively.

The Mcl-1 molecule [25] is an important and bonafide prosurvival protein for CLL. [26] However, as we found in our study, Mcl-1 has been shown to be involved in DNA damage and repair. [27] Other investigators have reported that cytotoxic DNA-damaging agents that cause an early apoptosis response lead to enhanced MCL1 gene expression in a p53-independent manner. [2730] Particularly, Mcl-1 is linked to regulating cell-cycle progression and is partially mediated through PCNA, interactions with CDK1, and ATR-dependent activation of Chk1 following DNA damage. [31-33] Overall, Mcl1 is highly overexpressed in many human cancers, is manipulated by malignant cells to escape apoptosis regulation, and has a unique role in the DNA damage response.

Mcl-1 is a cytosolic protein and in this location it has been established to inhibit endogenous or druginduced apoptosis. During DNA damage response, it is translocated to nucleus [27, 33-35]. Nuclear Mcl-1 interacts with many DNA repair/damage proteins such as $\mathrm{H} 2 \mathrm{AX}, \mathrm{Nbs} 1, \mathrm{Ku} 70$, and co-localizes with 53BP1 and is involved in homologous recombination pathway [35]. 


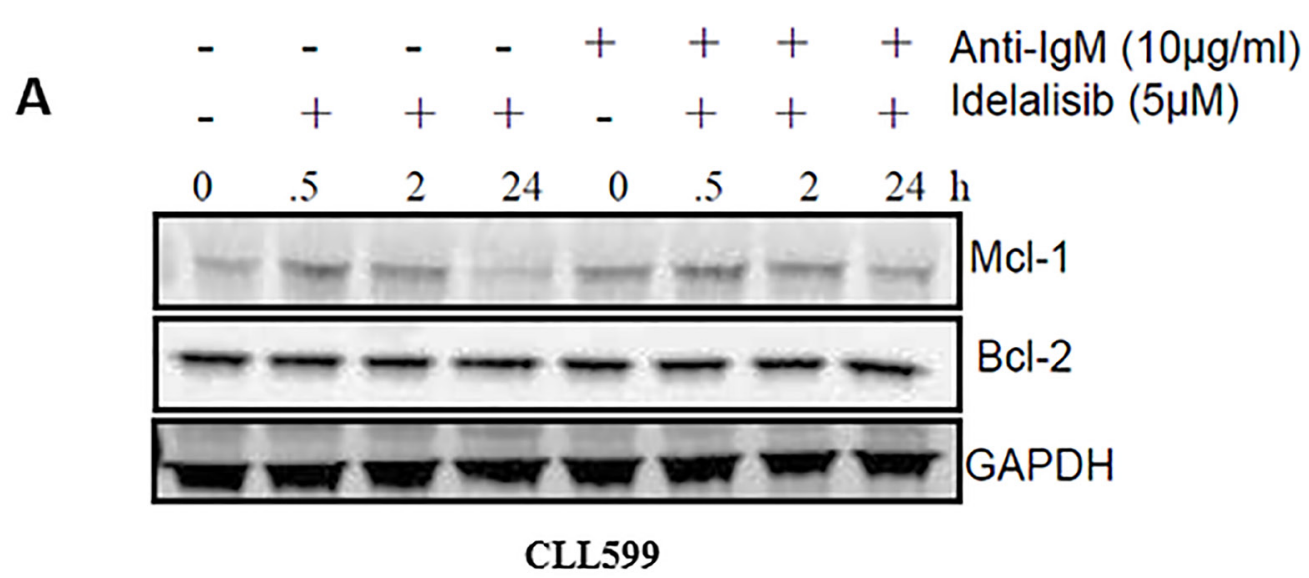

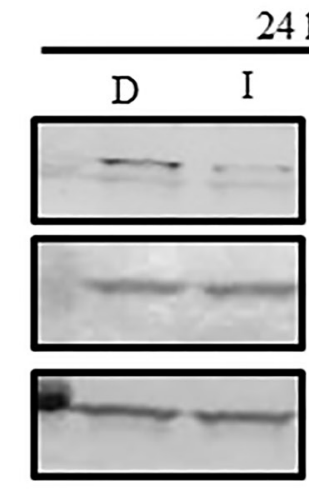

CLL525
$24 \mathrm{~h}$

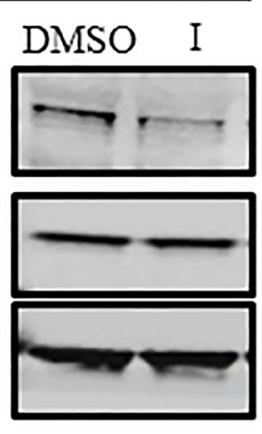

CLL103

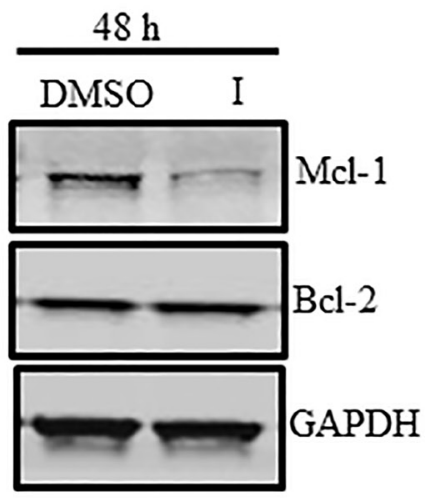

CLL103

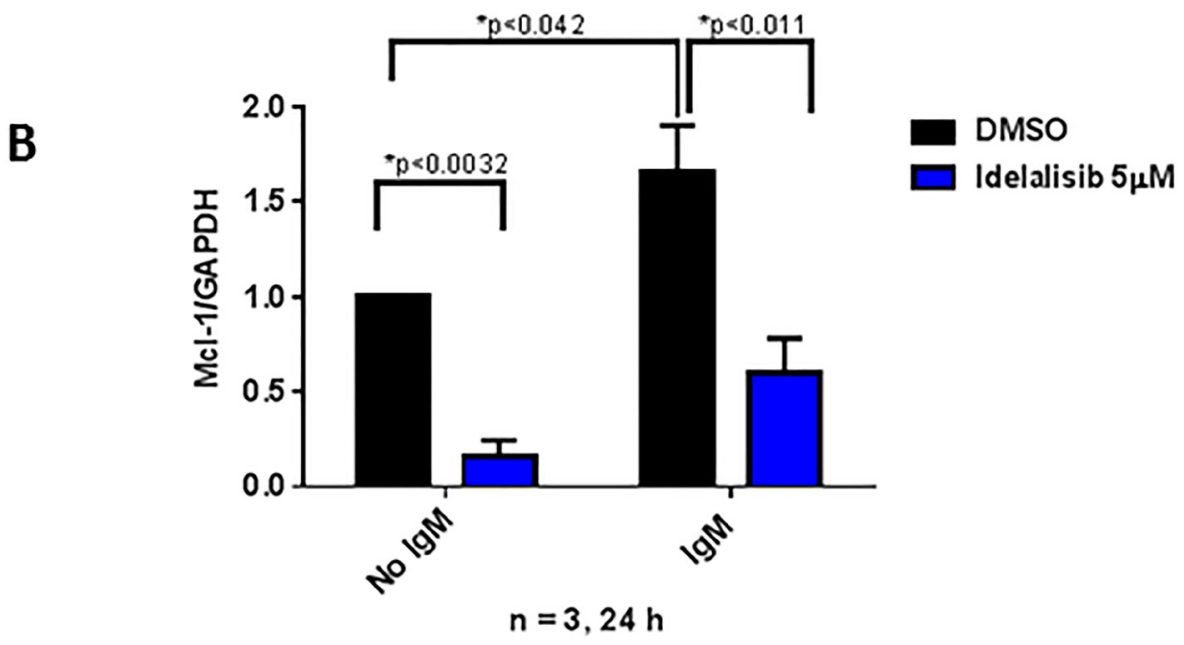

Figure 4: Effect of idelalisib on Mcl-1 protein levels. A. Decreased Mcl-1 protein expression, with no change in Bcl-2 protein expression, in idelalisib-treated CLL cells. Primary cells either unstimulated or stimulated with $\alpha \operatorname{IgM}(10 \mu \mathrm{g} / \mathrm{mL})$ for $30 \mathrm{minutes}$ and then were treated with DMSO (D) or idelalisib (I, $5 \mu \mathrm{M})$ for different times $(0,0.5,2,24$ hours [h]). Cells were harvested, and protein lysates were analyzed using immunoblots to detect the protein levels of MCL1 and BCL2. GAPDH was used as a control to check for equal protein loading. B. Immunoblots for three patient samples (from 4A) were quantified by measuring the ratios of Mcl-1 to GAPDH for idelalisibtreated samples, and these values were normalized to the DMSO control. The $\mathrm{p}$ values were calculated using paired $t$-test. 


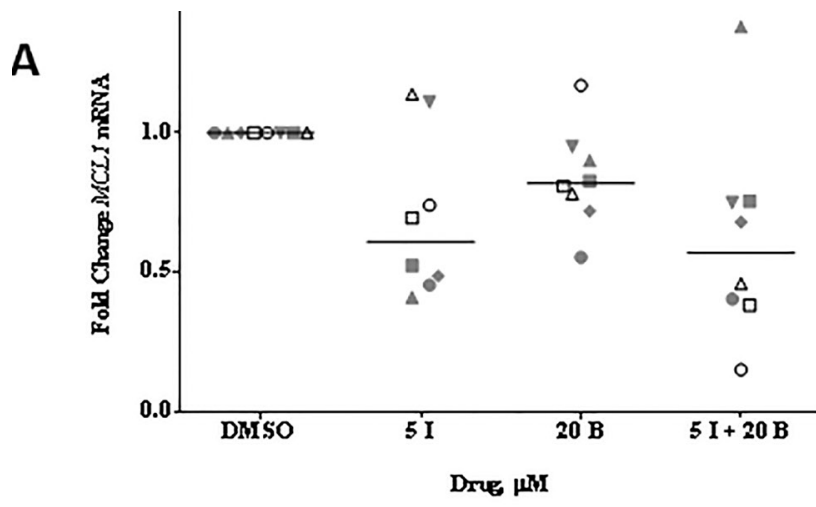

B
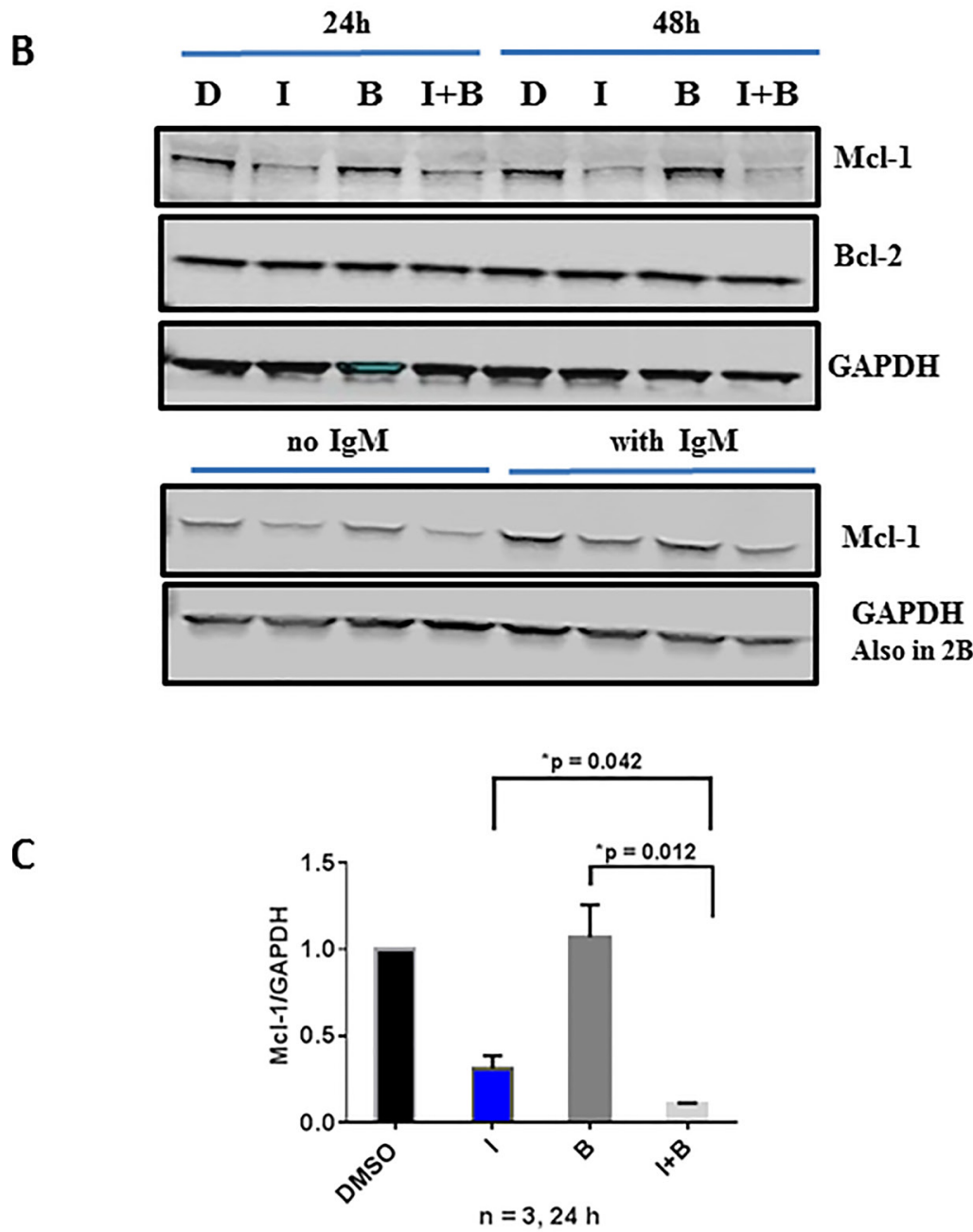

Figure 5: Comparison of single agent idelalisib, single agent bendamustine to combination regimen on MCL1 transcript and Mcl-1 protein levels. A. Primary cells were treated with DMSO, idelalisib (I, $5 \mu \mathrm{M})$ or bendamustine (B, $20 \mu \mathrm{M})$ alone, or in combination. Cells were harvested, and total RNA was extracted and analyzed by real-time RT-PCR with primers and probe for the MCL1 mRNA transcript. MCL1 gene expression was measured and normalized to the $18 S$ ribosomal RNA as an endogenous control, and each experiment was normalized to the DMSO control. The data are from 8 CLL patients (CLL516, CLL068, CLL454, CLL483, CLL354, CLL203, CLL653, and CLL075). Horizontal bar represents median value. B. Effect of idelalisib and bendamustine combination treatment on apoptotic protein levels in primary CLL cells. Primary cells were treated with DMSO, idelalisib (I, $5 \mu \mathrm{M}$ ) or bendamustine (B, 20 $\mu \mathrm{M})$ alone, or in combination $(5 \mu \mathrm{M} \mathrm{I}+20 \mu \mathrm{M}$ B) for 24 hours and 48 hours. Cells were harvested, and protein lysates were analyzed using immunoblots to detect the protein levels of Mcl-1 and Bcl-2. GAPDH was used as a control for equal protein loading. The lower immunoblot represents cells treated with or without IgM (same extract used in Figure 2B) and tested for $\gamma \mathrm{H} 2 \mathrm{AX}$. This immunoblot was from the same gel as in Figure 2B and hence same GAPDH is used. C. Immunoblots for three patient samples (from Figure 5B) were quantified by measuring the ratios of Mcl-1 and Bcl-2 to GAPDH for idelalisib- and bendamustine-treated samples, and these values were normalized to the DMSO control. Paired $t$-test was used to determine $p$ values. 
In addition to Mcl-1, several other pro and antisurvival members of the Bcl-2 family have been shown to participate in DNA repair. Pro-apoptotic protein Bid binds to RPA protein [36]. Bcl-2 has been shown to impact DNA double strand break repair [37] by inhibition of recruitment of Mre11 complex to the site of double strand breaks in the DNA [38]. Collectively, these reports establish mechanistic role of Bcl-2 family members in DNA damage repair which is in addition to the pro and anti-survival manifestations of these proteins.

Both MCL1 transcript and Mcl-1 protein are shortlived due to the presence of ARE-rich regions and PEST domains in transcript and proteins, respectively. Hence, even a short-term block or inhibition in transcription or protein translation results in a decline in MCL1 transcript and Mcl-1 protein levels. Furthermore, the stability of this protein is impacted by several pathways. Erk, a kinase involved in cancer cell survival, phosphorylates Mcl-1 which prevents proteasomal degradation of Mcl-1 [39, 40]. Proteasomal degradation of Mcl-1 is dependent on phosphorylation of this protein by GSK3 $\beta$ [41]. However, phosphorylation of GSK3 $\beta$ by Akt mitigates activity of GSK3 $\beta$ resulting in prolonged presence of Mcl-1 [42]. Both Akt and Erk are induced through BCR pathway [43,
44]. Corollary to this phenomenon, inhibition of BCR axis by PI3K/Akt inhibitors modulates Akt and Erk activities $[2,45]$ which may impact Mcl-1 protein stability and may induce degradation of this protein.

Down regulation of MCL1 transcript and protein levels was observed after treatment of CLL cells during in vitro incubations (Figures 3 and 4) of CLL cells with idelalisib. In concert to this observation, clinically, treatment of patients with idelalisib showed lowered expression of Mcl-1 protein in circulating CLL lymphocytes after 2, 4, and 12 weeks of idelalisib intake (Yang, Modi unpublished). Other small molecule targeted inhibitors of PI3K [45], BCR pathway [46], and BTK [47] also result in depletion or decrease in intracellular levels of Mcl-1 protein in CLL lymphocytes. Overall, decrease in Mcl-1 protein expression is a pharmacodynamic phenomenon in CLL cells after treatment with BCR pathway inhibitors.

The phase II clinical trial of bendamustine and rituximab in relapsed/refractory CLL disease, demonstrated $60 \%$ overall response-rate [48]. Although the overall response rate and $\mathrm{CR}$ rate are lower than the FCR therapy, this regimen is preferred for low untoward toxicity profile. To increase response rates, fludarabine

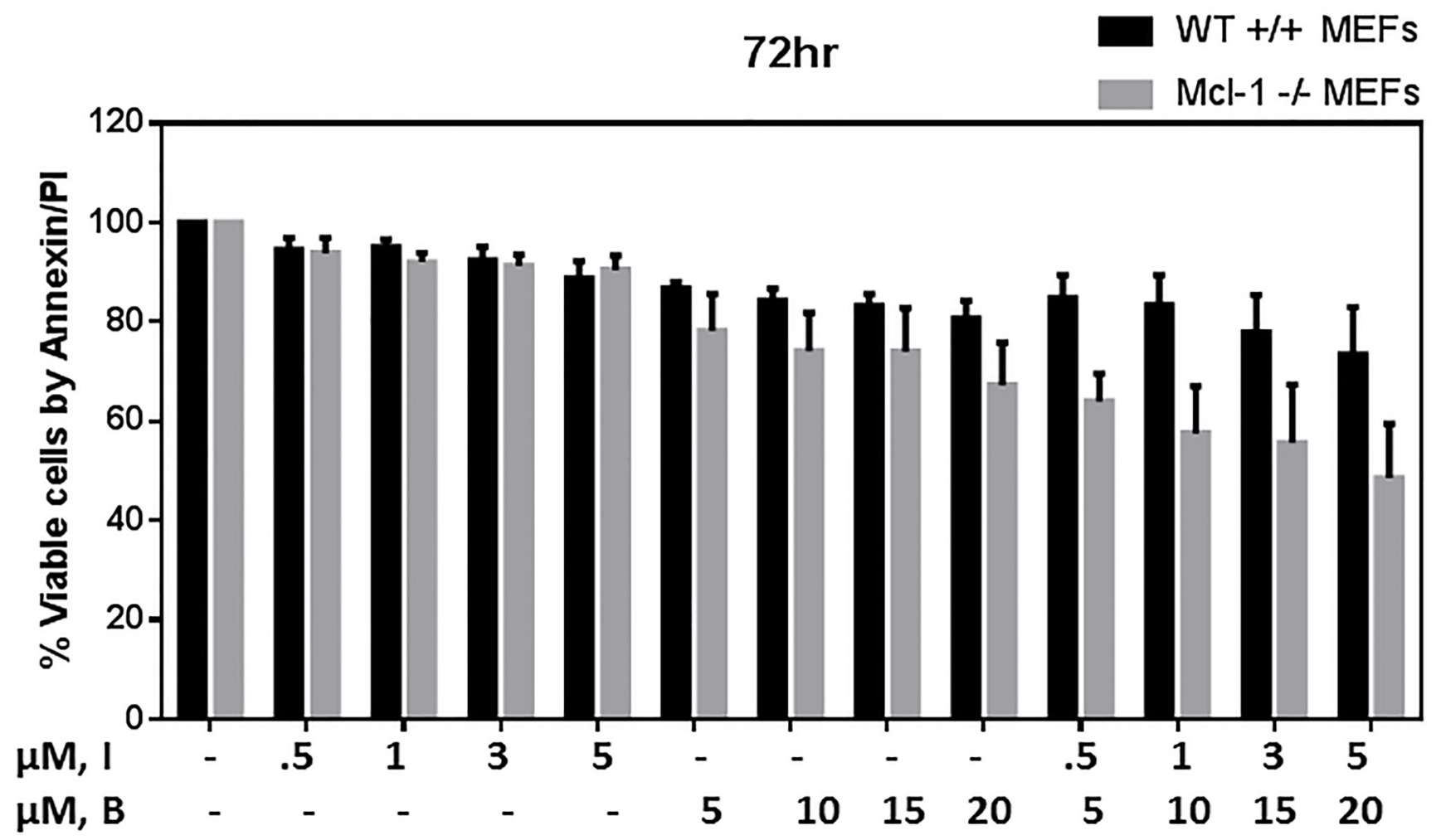

Figure 6: Modulation of Bendamustine-induced cytotoxicity in MEFs lacking MCL1. Increased cytotoxicity in bendamustinetreated mouse embryonic fibroblasts (MEFs) lacking MCL1 compared with wild-type (WT) MEFs. MCL1 ${ }^{\mathrm{w} / \mathrm{wt}}$ and MCL1 ${ }^{\Delta / \mathrm{null}}$ MEFs were treated with DMSO, idelalisib $(0.5 \mu \mathrm{M}, 1 \mu \mathrm{M}, 3 \mu \mathrm{M}, 5 \mu \mathrm{M})$ or bendamustine $(5 \mu \mathrm{M}, 10 \mu \mathrm{M}, 15 \mu \mathrm{M}, 20 \mu \mathrm{M})$ alone, or a combination of idelalisib and bendamustine $(0.5 \mu \mathrm{M}+5 \mu \mathrm{M}, 1 \mu \mathrm{M}+10 \mu \mathrm{M}, 3 \mu \mathrm{M}+15 \mu \mathrm{M}$, or $5 \mu \mathrm{M}+20 \mu \mathrm{M}$, respectively) for 72 hours. Cells were harvested, stained with Annexin V and propidium iodide (PI), and the amount of apoptotic cells in each treated sample was detected using flow cytometry. Experiments were done in triplicate, and the results show the averages $\pm \mathrm{SEM}$. 
[49], ibrutinib (HELIOS trial; [50]), and idelalisib [51] have been added to the bendamustine and rituximab couplet regimen. The HELIOS trial was a randomized study where bendamustine and rituximab combination was compared with the triplet of bendamustine and rituximab with ibrutinib. Addition of ibrutinib led to significant benefit for overall response rate and progression-free survival. Importantly, the triple combination did not add any cumulative toxicities [50]. Similar to this combination, preliminary and interim report also suggested that idelalisib improves progression-free survival when added to the bendamustine and rituximab couplet [51,52]. These trial results clearly suggest clinical benefit of adding BCR pathway inhibitor to bendamustine plus rituximab chemoimmunotherapy.

In conclusion, we demonstrate that the addition of idelalisib synergistically benefits bendamustineinduced cytotoxicity in CLL lymphocytes. Furthermore, idelalisib-mediated DNA damage response and decline in MCL1 mRNA and Mcl-1 protein levels may in-part be mechanisms of this synergistic cooperation.

\section{MATERIAL, PATIENTS, AND METHODS}

\section{Patient sample collection}

Peripheral blood was obtained from CLL patients (Supplemental Table 1) who had given written informed consent in accordance with the Declaration of Helsinki. The study protocol was approved by the Institutional Review Board of The UT MD Anderson Cancer Center. Peripheral blood mononuclear cells were isolated by Ficoll-Hypaque density gradient centrifugation (Atlanta Biologicals, Norcross, GA). Cells $\left(1 \times 10^{7} / \mathrm{mL}\right)$ were cultured in RPMI-1640 medium with $10 \%$ autologous patient serum and were freshly used. For in vitro BCR activation, CLL cells were stimulated with polyclonal goat $\mathrm{F}(\mathrm{ab}$ ')2 fragments of human IgM (MP Biomedicals, Santa Ana, CA).

\section{Mouse embryo fibroblast cell line}

Mouse embryonic fibroblasts (MEFs), wild-type and MCL1 deficient were generously provided by Dr. Joseph T. Opferman at St. Jude Children's Research Hospital (Memphis, TN) [25] Both cell lines are Simian virus (SV40)-transformed and the cells were maintained in Dulbecco modified Eagle medium with L-glutamine (DMEM; Invitrogen) media supplemented with $10 \%$ fetal bovine serum (FBS; Invitrogen), Pen/Strep, L-Glut, and non-essential amino acids (NEAA; GIBCO). Presence or absence of Mcl-1 protein in these cells were confirmed by Dr. Opferman's group as well as by our group using immunoblots. Cell lines were periodically tested for
Mycoplasma contamination using a MycoTect kit (Invitrogen). All experiments were conducted in cell passages less than 15 and were maintained at a logarithmic growth concentration between $10^{5}$ cells $/ \mathrm{mL}$ and $10^{6}$ cells/ $\mathrm{mL}$ with $80 \%$ confluency as determined by a Coulter channelyzer with less than $10 \%$ endogenous cell death confirmed by flow cytometry.

\section{Drugs}

Idelalisib (GS-1101 or CAL-101) was provided by Gilead Sciences, Inc., (Foster City, CA). Bendamustine hydrochloride was originally obtained from Cephalon (Frazer, PA; now Teva Pharmaceuticals Industries, Ltd., Petah Tikva, Israel) and was later purchased from Selleckchem (Houston, TX). Both drugs were used in micromolar concentrations that were chosen on the basis of reported plasma concentrations of the free drug in patients. $[1,2,5,12,14,20]$ For bendamustine we used generally $20 \mu \mathrm{M}$ exogenous drug. Bendamustine peak levels are $28 \mu \mathrm{M}$ [53] or $20-24 \mu \mathrm{M}$ at 90 and $120 \mathrm{mg} / \mathrm{m}^{2}$ $[54,55]$. For idelalisib, we generally used $20 \mu \mathrm{M}$. Because more than $84 \%$ of idelalisib binds to human plasma proteins [1], only $16 \%$ of the free drug is available to the cells during in vitro culture conditions. Hence, exogenous addition of $5 \mu \mathrm{M}$ idelalisib to in vitro culture may result in $0.8 \mu \mathrm{M}$ free idelalisib available for activity. Such free-drug levels in plasma are achieved during idelalisib therapy.

\section{Cytotoxicity assays}

For apoptotic assay, primary CLL cells were untreated or treated with idelalisib, bendamustine, or combination and stained with Annexin $\mathrm{V}$ and propidium iodide and counted using flow cytometry, as described previously. [56] Cells in all three quadrants (early apoptosis, late apoptosis, and necrosis) were included to obtain percent total cell death.

\section{$\gamma \mathrm{H} 2 \mathrm{AX}$ staining}

The cells obtained before and after incubation with drugs were washed with PBS and fixed in $6 \mathrm{~mL}$ ice-cold $70 \%$ ethanol and analyzed for $\mathrm{H} 2 \mathrm{AX}$ phosphorylation on the flow cytometry. The cells were then fixed with $4 \%$ fresh paraformaldehyde/PBS ( $\mathrm{pH}$ 7.4) at room temperature for $10 \mathrm{~min}$. After couple of washes with BSA/PBS, the cells were blocked with $5 \%$ goat serum for an hr. This was followed by incubation with anti-phospho-Histone H2AX (Ser139) mouse monoclonal antibody, clone JBW301, FITC conjugate (16-202A; Upstate, Billerica, MA) for 2 $\mathrm{hr}$. The labeled cells were washed and resuspended in PBS containing the counterstain propidium iodide $(15 \mu \mathrm{g} / \mathrm{mL})$ and RNAase (Roche, South San Francisco, CA) $(2.5 \mu \mathrm{g} /$ 
$\mathrm{mL}$ ) and incubated in dark for $5 \mathrm{~min}$ before analysis using FACScalibur (BD Biosciences, San Jose, CA). Data were expressed as fold increase of $\mathrm{H} 2 \mathrm{AX}$ phosphorylation. In addition to flow cytometry assay, immunoblot assays were also performed to test for $\mathrm{H} 2 \mathrm{AX}$ phosphorylation.

\section{Immunoblot analyses}

Extracts from cell lysates were quantitated for protein concentration using a DC protein assay kit (BioRad Laboratories, Hercules, CA, USA), loaded and transferred to nitrocellulose membranes (GE Osmonics Labstore, Minnetonka, MN, USA). Membranes were blocked for $1 \mathrm{~h}$ in licor blocking buffer, incubated with primary antibodies overnight at $4{ }^{\circ} \mathrm{C}$ against the following: After washing with PBS-Tween-20, membranes were incubated with infrared-labeled secondary antibodies (LICOR Inc., Lincoln, NE, USA) for an hour, scanned and visualized using LI-COR Odyssey Infrared Imager. [14] Antibodies for specific proteins and their catalog numbers were used and are listed in the table (Supplemental Table 2).

\section{RNA synthesis assay}

Primary CLL cells were either untreated or treated with idelalisib for the indicated time. For the last $30 \mathrm{~min}$, the cells were incubated with $\left[5,6-{ }^{3} \mathrm{H}\right]$-uridine $(1.0 \mathrm{mCi} /$ $\mathrm{mL}$ stock; Moravek Biochemicals, Brea, CA), and the radioactive counts were measured by scintillation counter. [14] Each treatment was done in triplicate and data were presented as percent of control where control is timematched untreated CLL cells.

\section{Transcript level measurements}

CLL lymphocytes were treated with DMSO or with idelalisib alone, bendamustine alone, or two drugs together for 24 hours. TaqMan real-time reverse transcription polymerase chain reaction assay was used to measure BCL2 and MCL1 transcript levels, which were normalized to $18 S$ ribosomal RNA as an endogenous control. [56]

\section{Statistical analysis}

Paired 2-tailed Student $t$-tests were performed using Prism-6 software (GraphPad Software, Inc., La Jolla, CA). For combination treatment, fractional analysis was used to determine whether the combination led to less than, equal to, or more than the additive effect on inducing apoptosis. [57] CalcuSyn software (CompuSyn Inc., Paramus, NJ) was used to determine the combination index.

\section{ACKNOWLEDGMENTS}

Authors are thankful to Jill Delsigne for critically editing the manuscript.

\section{CONFLICTS OF INTEREST}

V.G. received research funding from Gilead. Other authors do not have a conflict of interest.

\section{FUNDING}

This work was supported in part by grant P01CA81534 of the CLL Research Consortium from the National Cancer Institute, the Department of Health and Human Services, a CLL Global Research Foundation Alliance grant, and a Sponsored Research Agreement from Gilead.

\section{Authorship contribution}

P.M. designed the experiments, performed the experiments, analyzed the results, and wrote the manuscript. K.B. directed P.M. in the laboratory and reviewed the manuscript. Q.Y. assisted in experimental planning and reviewed the manuscript. M.J.K. and W.G.W. identified patients to obtain peripheral blood samples, provided clinical and patient-related input, and reviewed the manuscript. V.G. conceptualized and supervised the research, obtained funding, analyzed the data, and wrote and reviewed the manuscript.

\section{Editorial note}

This paper has been accepted based in part on peerreview conducted by another journal and the authors' response and revisions as well as expedited peer-review in Oncotarget.

\section{REFERENCES}

1. Yang Q, Modi P, Newcomb T, Quéva C, Gandhi V. Idelalisib: First-in-Class PI3K Delta Inhibitor for the Treatment of Chronic Lymphocytic Leukemia, Small Lymphocytic Leukemia, and Follicular Lymphoma. Clin Cancer Res. 2015; 21:1537-42.

2. Brown JR, Byrd JC, Coutre SE, Benson DM, Flinn IW, Wagner-Johnston ND, Spurgeon SE, Kahl BS, Bello C, Webb HK, Johnson DM, Peterman S, Li D, et al. Idelalisib, an inhibitor of phosphatidylinositol 3-kinase p1108, for relapsed/refractory chronic lymphocytic leukemia. Blood. 2014; 123:3390-97.

3. Lannutti BJ, Meadows SA, Herman SE, Kashishian A, Steiner B, Johnson AJ, Byrd JC, Tyner JW, Loriaux MM, 
Deininger M, Druker BJ, Puri KD, Ulrich RG, Giese NA. CAL-101, a p110delta selective phosphatidylinositol-3kinase inhibitor for the treatment of B-cell malignancies, inhibits PI3K signaling and cellular viability. Blood. 2011; 117:591-94.

4. Hoellenriegel J, Meadows SA, Sivina M, Wierda WG, Kantarjian H, Keating MJ, Giese N, O'Brien S, Yu A, Miller LL, Lannutti BJ, Burger JA. The phosphoinositide 3'-kinase delta inhibitor, CAL-101, inhibits B-cell receptor signaling and chemokine networks in chronic lymphocytic leukemia. Blood. 2011; 118:3603-12.

5. Herman SE, Gordon AL, Wagner AJ, Heerema NA, Zhao W, Flynn JM, Jones J, Andritsos L, Puri KD, Lannutti BJ, Giese NA, Zhang X, Wei L, et al. Phosphatidylinositol 3-kinase- $\delta$ inhibitor CAL-101 shows promising preclinical activity in chronic lymphocytic leukemia by antagonizing intrinsic and extrinsic cellular survival signals. Blood. 2010; 116:2078-88.

6. Fiorcari S, Brown WS, McIntyre BW, Estrov Z, Maffei R, O'Brien S, Sivina M, Hoellenriegel J, Wierda WG, Keating MJ, Ding W, Kay NE, Lannutti BJ, et al. The PI3kinase delta inhibitor idelalisib (GS-1101) targets integrinmediated adhesion of chronic lymphocytic leukemia (CLL) cell to endothelial and marrow stromal cells. PLoS One. 2013; 8:e83830.

7. Furman RR, Sharman JP, Coutre SE, Cheson BD, Pagel JM, Hillmen P, Barrientos JC, Zelenetz AD, Kipps TJ, Flinn I, Ghia P, Eradat H, Ervin T, et al. Idelalisib and rituximab in relapsed chronic lymphocytic leukemia. N Engl J Med. 2014; 370:997-1007.

8. Miller BW, Przepiorka D, de Claro RA, Lee K, Nie L, Simpson N, Gudi R, Saber H, Shord S, Bullock J, Marathe D, Mehrotra N, Hsieh LS, et al. FDA approval: idelalisib monotherapy for the treatment of patients with follicular lymphoma and small lymphocytic lymphoma. Clin Cancer Res. 2015; 21:1525-29.

9. O’Brien SM, Lamanna N, Kipps TJ, Flinn I, Zelenetz AD, Burger JA, Keating M, Mitra S, Holes L, Yu AS, Johnson DM, Miller LL, Kim Y, et al. A phase 2 study of idelalisib plus rituximab in treatment-naïve older patients with chronic lymphocytic leukemia. Blood. 2015; 126:2686-94.

10. Lampson BL, Kasar SN, Matos TR, Morgan EA, Rassenti L, Davids MS, Fisher DC, Freedman AS, Jacobson CA, Armand P, Abramson JS, Arnason JE, Kipps TJ, et al. Idelalisib given front-line for treatment of chronic lymphocytic leukemia causes frequent immune-mediated hepatotoxicity. Blood. 2016; 128:195-203.

11. Coutré SE, Barrientos JC, Brown JR, de Vos S, Furman RR, Keating MJ, Li D, O’Brien SM, Pagel JM, Poleski MH, Sharman JP, Yao NS, Zelenetz AD. Management of adverse events associated with idelalisib treatment: expert panel opinion. Leuk Lymphoma. 2015; 56:2779-86.

12. Gandhi V, Burger JA. Bendamustine in B-Cell Malignancies: The New 46-Year-Old Kid on the Block. Clin Cancer Res. 2009; 15:7456-61.
13. Cheson BD, Brugger W, Damaj G, Dreyling M, Kahl B, Kimby E, Ogura M, Weidmann E, Wendtner CM, Zinzani PL. Optimal use of bendamustine in hematologic disorders: treatment recommendations from an international consensus panel - an update. Leuk Lymphoma. 2016; 57:766-82.

14. El-Mabhouh AA, Ayres ML, Shpall EJ, Baladandayuthapani V, Keating MJ, Wierda WG, Gandhi V. Evaluation of bendamustine in combination with fludarabine in primary chronic lymphocytic leukemia cells. Blood. 2014; 123:3780-89.

15. Montraveta A, Lee-Vergés E, Roldán J, Jiménez L, Cabezas S, Clot G, Pinyol M, Xargay-Torrent S, Rosich L, Arimany-Nardí C, Aymerich M, Villamor N, LópezGuillermo A, et al. CD69 expression potentially predicts response to bendamustine and its modulation by ibrutinib or idelalisib enhances cytotoxic effect in chronic lymphocytic leukemia. Oncotarget. 2016; 7:5507-20. doi: 10.18632/ oncotarget.6685.

16. Roué G, López-Guerra M, Milpied P, Pérez-Galán P, Villamor N, Montserrat E, Campo E, Colomer D. Bendamustine is effective in p53-deficient B-cell neoplasms and requires oxidative stress and caspase-independent signaling. Clin Cancer Res. 2008; 14:6907-15.

17. Fillingham J, Keogh MC, Krogan NJ. GammaH2AX and its role in DNA double-strand break repair. Biochem Cell Biol. 2006; 84:568-77.

18. Bader AG, Kang S, Zhao L, Vogt PK. Oncogenic PI3K deregulates transcription and translation. Nat Rev Cancer. 2005; 5:921-29.

19. Balakrishnan K, Gandhi V. Bcl-2 antagonists: a proof of concept for CLL therapy. Invest New Drugs. 2013; 31:1384-94.

20. Leoni LM, Bailey B, Reifert J, Bendall HH, Zeller RW, Corbeil J, Elliott G, Niemeyer CC. Bendamustine (Treanda) displays a distinct pattern of cytotoxicity and unique mechanistic features compared with other alkylating agents. Clin Cancer Res. 2008; 14:309-17.

21. Gandhi V. Metabolism and mechanisms of action of bendamustine: rationales for combination therapies. Semin Oncol. 2002; 29:4-11.

22. Knauf WU, Lissichkov $\mathrm{T}$, Aldaoud A, Liberati A, Loscertales J, Herbrecht R, Juliusson G, Postner G, Gercheva L, Goranov S, Becker M, Fricke HJ, Huguet F, et al. Phase III randomized study of bendamustine compared with chlorambucil in previously untreated patients with chronic lymphocytic leukemia. J Clin Oncol. 2009; 27:4378-84.

23. Matsuoka S, Ballif BA, Smogorzewska A, McDonald ER 3rd, Hurov KE, Luo J, Bakalarski CE, Zhao Z, Solimini N, Lerenthal Y, Shiloh Y, Gygi SP, Elledge SJ. ATM and ATR substrate analysis reveals extensive protein networks responsive to DNA damage. Science. 2007; 316:1160-66.

24. Shiloh Y. ATM and related protein kinases: safeguarding genome integrity. Nat Rev Cancer. 2003; 3:155-68. 
25. Opferman JT, Letai A, Beard C, Sorcinelli MD, Ong CC, Korsmeyer SJ. Development and maintenance of B and T lymphocytes requires antiapoptotic MCL-1. Nature. 2003; 426:671-76.

26. Pepper C, Lin TT, Pratt G, Hewamana S, Brennan P, Hiller L, Hills R, Ward R, Starczynski J, Austen B, Hooper L, Stankovic T, Fegan C. Mcl-1 expression has in vitro and in vivo significance in chronic lymphocytic leukemia and is associated with other poor prognostic markers. Blood. 2008; 112:3807-17.

27. Jamil S, Stoica C, Hackett TL, Duronio V. MCL-1 localizes to sites of DNA damage and regulates DNA damage response. Cell Cycle. 2010; 9:2843-55.

28. Zhan Q, Bieszczad CK, Bae I, Fornace AJ Jr, Craig RW. Induction of BCL2 family member MCL1 as an early response to DNA damage. Oncogene. 1997; 14:1031-39.

29. Yang T, Buchan HL, Townsend KJ, Craig RW. MCL-1, a member of the BLC-2 family, is induced rapidly in response to signals for cell differentiation or death, but not to signals for cell proliferation. J Cell Physiol. 1996; 166:523-36.

30. Kozopas KM, Yang T, Buchan HL, Zhou P, Craig RW. MCL1, a gene expressed in programmed myeloid cell differentiation, has sequence similarity to BCL2. Proc Natl Acad Sci USA. 1993; 90:3516-20.

31. Fujise K, Zhang D, Liu J, Yeh ET. Regulation of apoptosis and cell cycle progression by MCL1. Differential role of proliferating cell nuclear antigen. J Biol Chem. 2000; 275:39458-65.

32. Jamil S, Mojtabavi S, Hojabrpour P, Cheah S, Duronio V. An essential role for MCL-1 in ATR-mediated CHK1 phosphorylation. Mol Biol Cell. 2008; 19:3212-20.

33. Jamil S, Sobouti R, Hojabrpour P, Raj M, Kast J, Duronio $\mathrm{V}$. A proteolytic fragment of Mcl-1 exhibits nuclear localization and regulates cell growth by interaction with Cdk1. Biochem J. 2005; 387:659-67.

34. Pawlikowska P, Leray I, de Laval B, Guihard S, Kumar R, Rosselli F, Porteu F. ATM-dependent expression of IEX1 controls nuclear accumulation of Mcl-1 and the DNA damage response. Cell Death Differ. 2010; 17:1739-50.

35. Mattoo AR, Pandita RK, Chakraborty S, Charaka V, Mujoo K, Hunt CR, Pandita TK. MCL-1 Depletion Impairs DNA Double-Strand Break Repair and Reinitiation of Stalled DNA Replication Forks. Mol Cell Biol. 2017; 37:

36. Liu Y, Vaithiyalingam S, Shi Q, Chazin WJ, Zinkel SS. BID binds to replication protein A and stimulates ATR function following replicative stress. Mol Cell Biol. 2011; 31:4298-309.

37. Wang Q, Gao F, May WS, Zhang Y, Flagg T, Deng X. $\mathrm{Bcl} 2$ negatively regulates DNA double-strand-break repair through a nonhomologous end-joining pathway. Mol Cell. 2008; 29:488-98.

38. Xie M, Park D, You S, Li R, Owonikoko TK, Wang Y, Doetsch PW, Deng X. Bcl2 inhibits recruitment of Mre11 complex to DNA double-strand breaks in response to high- linear energy transfer radiation. Nucleic Acids Res. 2015; 43:960-72.

39. Domina AM, Vrana JA, Gregory MA, Hann SR, Craig RW. MCL1 is phosphorylated in the PEST region and stabilized upon ERK activation in viable cells, and at additional sites with cytotoxic okadaic acid or taxol. Oncogene. 2004; 23:5301-15.

40. Gandhi V, Balakrishnan K, Chen LS. Mcl-1: the 1 in CLL. Blood. 2008; 112:3538-40.

41. Maurer U, Charvet C, Wagman AS, Dejardin E, Green DR. Glycogen synthase kinase-3 regulates mitochondrial outer membrane permeabilization and apoptosis by destabilization of MCL-1. Mol Cell. 2006; 21:749-60.

42. Thomas LW, Lam C, Edwards SW. Mcl-1; the molecular regulation of protein function. FEBS Lett. 2010; 584:298189.

43. Woyach JA, Johnson AJ, Byrd JC. The B-cell receptor signaling pathway as a therapeutic target in CLL. Blood. $2012 ; 120: 1175-84$.

44. Limnander A, Depeille P, Freedman TS, Liou J, Leitges M, Kurosaki T, Roose JP, Weiss A. STIM1, PKC- $\delta$ and RasGRP set a threshold for proapoptotic Erk signaling during B cell development. Nat Immunol. 2011; 12:425-33.

45. Balakrishnan K, Peluso M, Fu M, Rosin NY, Burger JA, Wierda WG, Keating MJ, Faia K, O’Brien S, Kutok JL, Gandhi V. The phosphoinositide-3-kinase (PI3K)-delta and gamma inhibitor, IPI-145 (Duvelisib), overcomes signals from the PI3K/AKT/S6 pathway and promotes apoptosis in CLL. Leukemia. 2015; 29:1811-22.

46. López-Guerra M, Xargay-Torrent S, Pérez-Galán P, SaboritVillarroya I, Rosich L, Villamor N, Aymerich M, Roué G, Campo E, Montserrat E, Colomer D. Sorafenib targets BCR kinases and blocks migratory and microenvironmental survival signals in CLL cells. Leukemia. 2012; 26:1429-32.

47. Cervantes-Gomez F, Lamothe B, Woyach JA, Wierda WG, Keating MJ, Balakrishnan K, Gandhi V. Pharmacological and Protein Profiling Suggests Venetoclax (ABT-199) as Optimal Partner with Ibrutinib in Chronic Lymphocytic Leukemia. Clin Cancer Res. 2015; 21:3705-15.

48. Fischer K, Cramer P, Busch R, Stilgenbauer S, Bahlo J, Schweighofer CD, Böttcher S, Staib P, Kiehl M, Eckart MJ, Kranz G, Goede V, Elter T, et al. Bendamustine combined with rituximab in patients with relapsed and/or refractory chronic lymphocytic leukemia: a multicenter phase II trial of the German Chronic Lymphocytic Leukemia Study Group. J Clin Oncol. 2011; 29:3559-66.

49. Jain N, Balakrishnan K, Ferrajoli A, O'Brien SM, Burger JA, Kadia TM, Cortes JE, Ayres ML, Tambaro FP, Keating MJ, Gandhi V, Wierda WG. A phase I-II trial of fludarabine, bendamustine and rituximab (FBR) in previously treated patients with CLL. Oncotarget. 2016 Sep 15. doi: 10.18632/ oncotarget.12054. [Epub ahead of print].

50. Chanan-Khan A, Cramer P, Demirkan F, Fraser G, Silva RS, Grosicki S, Pristupa A, Janssens A, Mayer J, 
Bartlett NL, Dilhuydy MS, Pylypenko H, Loscertales J, et al, and HELIOS investigators. Ibrutinib combined with bendamustine and rituximab compared with placebo, bendamustine, and rituximab for previously treated chronic lymphocytic leukaemia or small lymphocytic lymphoma (HELIOS): a randomised, double-blind, phase 3 study. Lancet Oncol. 2016; 17:200-11.

51. Zelenetz AD, Robak T, Coiffier B, Delgado J, Marlton P, Adewoye AH, Kim Y, Dreiling LK, Hillmen P. Idelalisib Plus Bendamustine and Rituximab (BR) Is Superior to BR Alone in Patients with Relapsed/Refractory Chronic Lymphocytic Leukemia: Results of a Phase 3 Randomized Double-Blind Placebo-Controlled Study. Blood. 2015; 126:LBA-5.

52. Starr P. Idelalisib Improves Survival When Added to Bendamustine plus Rituximab in Patients with CLL. Am Health Drug Benefits. 2016; 9:17.

53. Owen JS, Melhem M, Passarell JA, D'Andrea D, Darwish M, Kahl B. Bendamustine pharmacokinetic profile and exposure-response relationships in patients with indolent non-Hodgkin's lymphoma. Cancer Chemother Pharmacol. 2010; 66:1039-49.

54. Rasschaert M, Schrijvers D, Van den Brande J, Dyck J, Bosmans J, Merkle K, Vermorken JB. A phase I study of bendamustine hydrochloride administered day $1+2$ every 3 weeks in patients with solid tumours. Br J Cancer. 2007; 96:1692-98.

55. Ogura M, Uchida T, Taniwaki M, Ando K, Watanabe T, Kasai M, Matsumoto Y, Shimizu D, Ogawa Y, Ohmachi
K, Yokoyama H, Tobinai K, and Japanese Bendamustine Lymphoma Study Group. Phase I and pharmacokinetic study of bendamustine hydrochloride in relapsed or refractory indolent B-cell non-Hodgkin lymphoma and mantle cell lymphoma. Cancer Sci. 2010; 101:2054-58.

56. Balakrishnan K, Burger JA, Fu M, Doifode T, Wierda WG, Gandhi V. Regulation of Mcl-1 expression in context to bone marrow stromal microenvironment in chronic lymphocytic leukemia. Neoplasia. 2014; 16:1036-46.

57. Chou TC. Drug combination studies and their synergy quantification using the Chou-Talalay method. Cancer Res. 2010; 70:440-46. 